\title{
Prepartum dietary energy intake affects metabolism and health during the periparturient period in primiparous and multiparous Holstein cows ${ }^{1}$
}

\author{
N. A. Janovick, ${ }^{*}$ Y. R. Boisclair,† and J. K. Drackley ${ }^{\star 2}$ \\ *Department of Animal Sciences, University of Illinois, Urbana 61801 \\ †Department of Animal Science, Cornell University, Ithaca, NY 14853
}

\begin{abstract}
An experiment was conducted to determine the effect of prepartum plane of energy intake on metabolic profiles related to lipid metabolism and health in blood and liver. Primiparous $(\mathrm{n}=24)$ and multiparous (n $=23$ ) Holsteins were randomly assigned by expected date of parturition to 1 of 3 prepartum energy intakes. A high energy diet [1.62 Mcal of net energy for lactation $\left(\mathrm{NE}_{\mathrm{L}}\right) / \mathrm{kg} ; 15 \%$ crude protein] was fed for either ad libitum intake or restricted intake to supply $150 \%$ (OVR) or $80 \%$ (RES) of energy requirements for dry cows in late gestation. To limit energy intake to $100 \%$ of National Research Council requirements at ad libitum intake, chopped wheat straw was included as $31.8 \%$ of dry matter for a control diet (CON; 1.21 Mcal of $\mathrm{NE}_{\mathrm{L}} /$ $\mathrm{kg}$ of dry matter; $14.2 \%$ crude protein). Regardless of parity group, OVR cows had greater concentrations of glucose, insulin, and leptin in blood prepartum compared with either CON or RES cows; however, dietary effects did not carry over to the postpartum period. Prepartum nonesterified fatty acids (NEFA) were lower in OVR cows compared with either CON or RES cows. Postpartum, however, OVR cows had evidence of greater mobilization of triacylglycerol (TAG) from adipose tissue as NEFA were higher than in CON or RES cows, especially within the first $10 \mathrm{~d}$ postpartum. Prepartum $\beta$-hydroxybutyrate (BHBA) was not affected by diet before parturition; however, within the first $10 \mathrm{~d}$ postpartum, OVR cows had greater BHBA than CON or RES cows. Prepartum diet did not affect liver composition prepartum; however, OVR cows had greater total lipid and TAG concentrations and lower glycogen postpartum than CON or RES cows. Frequency of ketosis and displaced abomasum was greater for OVR cows compared with CON or RES cows postpar-
\end{abstract}

Received March 29, 2010.

Accepted November 23, 2010

${ }^{1}$ Supported by State of Illinois and USDA-CSREES regional research funds appropriated to the Illinois Agricultural Experiment Station (projects W-181 and W-1181) and by USDA-CSREES Section 1433 Animal Health and Disease funds.

${ }^{2}$ Corresponding author: drackley@illinois.edu tum. Controlling or restricting prepartum energy intake yielded metabolic results that were strikingly similar both prepartum and postpartum, independent of parity group. The use of a bulky diet controlled prepartum energy intake in multiparous and primiparous cows, improved metabolic status postpartum, and reduced the incidence of health problems. When metabolic profiles are considered collectively, cows overfed energy prepartum exhibited an "overnutrition syndrome" with characteristics of clinical symptoms displayed by diabetic or obese nonruminant subjects. This syndrome likely contributed to metabolic dysfunction postpartum.

Key words: periparturient cow, energy intake, fatty liver, lipid metabolism

\section{INTRODUCTION}

Several studies in our research group (Grum et al., 1996; Dann et al., 2006; Douglas et al., 2006) and by others (Rukkwamsuk et al., 1998, 1999; Herdt, 2000) concur that overconsumption of energy prepartum is detrimental to cow health and liver function postpartum. Consensus is lacking, however, on appropriate dietary strategies to control energy intake prepartum. Prepartum diets formulated with higher energy density do not physically limit intake in multiparous or primiparous cows (VandeHaar et al., 1999; Mashek and Beede, 2001; Rabelo et al., 2003), allowing them to over-consume energy relative to their requirements. Overconsumption of energy prepartum often results in larger decreases in DMI prepartum compared with cows having controlled intake prepartum (Agenäs et al., 2003; Dann et al., 2006; Douglas et al., 2006; Guo et al., 2007). Large changes in prepartum DMI have been linked to greater mobilization of adipose tissue triacylglycerol (TAG) as well as increased deposition of lipid and TAG in liver postpartum (Drackley et al., 2005; Grummer et al., 2004).

The negative energy balance of early lactation is accompanied by an insulin-resistant state in tissues such as adipose and skeletal muscle to ensure that nutrients are spared to provide an adequate supply to the mammary gland (Bauman, 2000). Circulating NEFA are 
used as an indirect measure of mobilization of TAG from adipose tissue, which is greater in early lactation than in mid lactation (Mashek et al., 2001). Effects of high NEFA in circulation and deposition of TAG in the liver are analogous to those seen in nonruminant subjects during insulin resistance and development of type II diabetes (McGarry, 2002; Jin et al., 2005; Desvergne et al., 2006). In this context, cows may fail to adapt to negative energy balance in early lactation because of similar trends in metabolic dysfunction before parturition. Specifically, such cows exhibit hyperglycemia, hyperinsulinemia, and insulin resistance (similar to type II diabetes in humans) during late gestation (Holtenius, 1993; Herdt, 2000). Thus, hyperglycemia and hyperinsulinemia may precede the development of clinical signs of fatty liver disease or ketosis in dairy cows. If similar metabolic dysfunction occurs in cows as it does in subjects with type II diabetes, feeding strategies that prevent hyperglycemia, hyperinsulinemia, and large mobilization of adipose tissue TAG postpartum would be beneficial. Furthermore, because circulating NEFA are proportionally related to uptake of NEFA by the liver (Reynolds et al., 2003), strategies that decrease NEFA in circulation postpartum should decrease risk for fatty liver and ketosis.

A greater inclusion of bulky, lower quality forages in prepartum diets increases NDF content and limits voluntary DMI (NRC, 2001), thereby limiting total nutrient consumption. Forages such as chopped wheat straw have been used successfully to limit prepartum energy intake and improve transition health in the field (Beever, 2006; Drackley and Dann, 2008). Dann et al. (2006) included chopped wheat straw in prepartum diets to control intake during the far-off dry period. Allowing cows to consume $>50 \%$ more energy than NRC (2001) recommendations during the far-off dry period resulted in negative effects on metabolism and health compared with controlling intake, regardless of how cows were fed during the close-up period. In that study, no group of cows was limited to approximately $100 \%$ of energy requirements over the entire dry period and so effects of limited energy intake over the entire dry period remain unknown. Furthermore, few data are available regarding the effects of limiting energy intake for primiparous cows, which might be detrimental to milk yield because of requirements for growth as well as for pregnancy and lactation (NRC, 2001).

Our hypothesis was that controlling prepartum energy intake by using a bulky diet would yield results similar to restricting energy intake by offering less feed. This nutritional management strategy would allow ad libitum intake, yet prevent the "overnutrition syndrome" often observed in periparturient dairy cows that overconsume energy prepartum. Our first objective was to determine the effect of controlling prepartum energy intake over the entire dry period on blood metabolites related to lipid metabolism, liver composition, and frequency of health problems. Because the majority of research on transition period nutrition has focused on multiparous cows, our second objective was to compare dietary effects on periparturient metabolism and health between primiparous and multiparous cows.

\section{MATERIALS AND METHODS}

\section{Animal Management}

All procedures were conducted under protocols approved by the University of Illinois Institutional Animal Care and Use Committee. Complete details of animal management and diets were described by Janovick and Drackley (2010). In brief, both primiparous and multiparous Holstein cows were enrolled in this study. From first cow assignment to last cow completion required 317 d (late March 2005 through early February 2006). Multiparous cows were dried off $65 \mathrm{~d}$ before expected parturition and randomly assigned by expected date of parturition to 1 of 3 dry period nutrition treatments. Groups were balanced for previous mature-equivalent milk or predicted milk yield for heifers. For the first group, a high energy diet was fed for ad libitum intake (OVR) to provide at least $150 \%$ of NRC (2001) energy requirements for dry cows in late gestation. The same diet was fed in restricted amounts (RES) to supply $80 \%$ of NRC (2001) energy requirements to a second group, similar to previous studies in our laboratory (Dann et al., 2005, 2006; Douglas et al., 2006). Restriction was accomplished by limiting the amount of TMR fed to cows housed in individual tie stalls, with amounts fed based on calculations relative to individual BW. For the third group, energy intake was limited to about $100 \%$ of NRC requirement at ad libitum intake using a bulky high roughage control (CON) diet. Cows remained on their respective treatments through parturition; however, a close-up diet, formulated to be similar in nutrient composition to the far-off diet but with negative DCAD balance, was fed from $-21 \mathrm{~d}$ to parturition.

At $35 \mathrm{~d}$ before expected parturition, 24 primiparous heifers were randomly assigned by expected date of parturition to the same far-off dietary treatments as multiparous cows. These cows did not receive the diets altered for DCAD balance closer to parturition. From parturition through 60 DIM, both multiparous and primiparous cows consumed a lactation diet balanced to meet or exceed NRC (2001) requirements for cows in early lactation at ad libitum intake. Both pre- and postpartum diets were mixed daily and fed as TMR, 
which were offered in equal portions at 1100 and 1700 $\mathrm{h}$ each day. Cows fed RES had no orts at any time during the prepartum period. Alfalfa hay (approximately 3 $\mathrm{kg}$ ) was top-dressed onto the lactation TMR daily from parturition through 10 DIM. Cows were milked twice daily at 0300 and $1500 \mathrm{~h}$.

\section{Measurements, Sampling, and Analyses}

Blood samples were obtained from the coccygeal vein or artery at $0900 \mathrm{~h}$ (after feed refusals were removed and before the morning feeding) $1 \mathrm{~d}$ before dietary treatments began, and then weekly through $3 \mathrm{wk}$ before expected parturition; $\mathrm{d}-21,-19,-16$, and -13 ; daily from d -10 through 10 ; and d 13, 16, 19, 21, 28, 35, 42,49 , and 56 relative to parturition. Mean actual days of blood sampling were the same as target days, with standard deviations ranging from 0.1 to $0.9 \mathrm{~d}$. Blood sampling was adjusted so that it occurred $1 \mathrm{~d}$ before any planned liver biopsy except during daily blood sampling. Blood was collected into evacuated serum separator tubes (Becton Dickinson Vacutainer Systems, Franklin Lakes, NJ) containing clot activator and into evacuated plasma tubes (Becton Dickinson Vacutainer Systems) containing $\mathrm{K}_{3}$ EDTA. Plasma tubes were immediately placed on ice after collection for transport to the laboratory. All tubes were centrifuged at 1,300 $\times g$ for 10 min to obtain serum and plasma, which were divided into aliquots and stored at $-20^{\circ} \mathrm{C}$ until analysis.

A commercially available enzymatic-colorimetric kit was used to determine concentration of NEFA in plasma (NEFA C kit, Wako Chemicals USA Inc., Richmond, VA) as modified by Johnson and Peters (1993). Insulin in serum was measured using a RIA kit (Coata-Count Insulin kit, Diagnostic Products Corp., Los Angeles, CA) as modified by Studer et al. (1993). Concentrations of albumin (Doumas et al., 1971; Albumin Plus kit, Roche Diagnostics Corp., Indianapolis, IN), glucose (Peterson and Young, 1968; glucose/HK kit, Roche Diagnostics), and BHBA (Williamson and Mellanby, 1974; BHBA kit number 310-A, Sigma Chemical Co., St. Louis, MO) were measured in serum using an autoanalyzer at the University of Illinois Clinical Pathology Laboratory. Leptin was measured in serum using a radioimmunoassay procedure as described by Ehrhardt et al. (2000). For determination of NEFA and BHBA concentration in blood, weekly time points were used, as well as more frequent time points both pre-and postpartum. For NEFA, these extra time points were d $-10,-7$ through 7 , and 10 relative to parturition and for BHBA, these extra time points were $\mathrm{d}-4,-1,1$, and 4 relative to parturition. For insulin, glucose, and leptin, weekly time points pre- and postpartum were used for analysis. Albumin was evaluated on $\mathrm{d}-7,0$, and 7 relative to parturition.

Liver was sampled via puncture biopsy (Hughes, 1962) from cows under local anesthesia at $0700 \mathrm{~h}$ on $\mathrm{d}-65(-68 \pm 4.9 \mathrm{~d}$, mean $\pm \mathrm{SD}$ for day relative to actual parturition) for multiparous cows or $-42(-40$ \pm 6.4 ) relative to parturition for primiparous cows. For all cows, regardless of parity, liver also was sampled using the same technique on $\mathrm{d}-14(-16 \pm 3.9), 1$ (1 $\pm 0.3), 14(14 \pm 0.7), 28(29 \pm 1.0)$, and $49(43 \pm 0.9)$ relative to parturition. Liver tissue was immediately frozen in liquid $\mathrm{N}$ and later analyzed for concentrations of total lipid (Hara and Radin, 1978), TAG (Fletcher, 1968; Foster and Dunn, 1973), and glycogen (Lo et al., 1970).

\section{Statistical Analyses}

One multiparous cow in the OVR group developed toxic mastitis in wk 4 of lactation. This cow was killed and, therefore, for wk 5 to 8 postpartum $\mathrm{n}=7$ for observations in this group. All other levels of dietary treatment group by parity were balanced $(\mathrm{n}=8)$ postpartum. To avoid problems with fitting covariance structure, pre- and postpartum data and data from the day of parturition were analyzed separately. Data were analyzed as a randomized design using the MIXED procedure of SAS (SAS Institute Inc., Cary, NC) with the following model:

$$
\begin{gathered}
y_{i j k l}=\mu \\
+W_{i}+P_{j}+W P_{i j}+T_{k}+W T_{i k} \\
+P T_{j k}+W P T_{i j k}+C_{(i j k) l},
\end{gathered}
$$

where $y_{i j k l}=$ an observation from the $i$ th day relative to calving, $j$ th parity, $k$ th treatment, and $l$ th cow; $\mu=$ the grand mean; $W_{i}=$ effect of the $i$ th day; $P_{j}=$ effect of the $j$ th parity; $W P_{i j}=$ effect of the day by parity interaction; $T_{k}=$ effect of the $k$ th treatment; $W T_{i k}=$ effect of the day by treatment interaction; $P T_{j k}=$ effect of the parity by treatment interaction; $W P T_{i j k}=$ effect of the day by parity by treatment interaction; and $C_{(i j k) l}$ $=$ random experimental error from the $l$ th cow nested within the $i$ th day, $j$ th parity, and $k$ th treatment.

The REPEATED statement was used for variables measured over time (blood metabolites and liver lipid, TAG, and glycogen). For data from the day of parturition, the MIXED procedure of SAS was used without the REPEATED statement, and week or day relative to calving and all associated interactions were removed from the model. The random error term used for all mixed models was cow within breed and treatment and the covariance structure yielding the lowest Akaike's information criterion was used (Littell et al., 1998). 
Using this methodology, an autoregressive covariance structure best fit the data. Degrees of freedom were estimated by using the Satterthwaite option in the model statement. When significant interactions with treatment occurred, contrast statements were constructed to explore differences among time and treatment means. Covariate adjustment was used for NEFA, glucose, and leptin, using their respective pretreatment concentrations. Health and twinning data were analyzed with the FREQ procedure in SAS, and interpreted using Fisher's exact test probabilities. Significance was declared when $P \leq 0.05$, and tendencies or trends were declared at $0.05<P \leq 0.10$.

\section{RESULTS AND DISCUSSION}

\section{Design and Production Data}

Multiparous cows consumed far-off diets for $42 \pm 0.5$ $\mathrm{d}$ and close-up diets for $24 \pm 4.9 \mathrm{~d}$ before parturition. Primiparous cows consumed prepartum diets for $40 \pm$ $4.8 \mathrm{~d}$. Because multiparous cows were fed diets for a longer period prepartum compared with primiparous cows, we recognize that our discussion of parity differences includes the possibility that some observed differences may have resulted from the duration of time experimental diets were fed. This fact cannot be entirely separated from biological differences between primiparous and multiparous cows with regard to metabolism either pre- or postpartum. As discussed previously (Janovick and Drackley, 2010), however, it is invaluable to gain insight on how prepartum dietary management affects metabolism of both groups because primiparous and multiparous cows are often housed and fed together prepartum in practical settings. Pretrial data points are provided for multiparous cows as a point of reference but statistical comparisons were made between parities for matching periods only.

Data for DMI, milk production, BCS, BW, and energy balance were reported previously (Janovick and Drackley, 2010). Briefly, multiparous and primiparous cows assigned to OVR gained BCS during the dry period (initial BCS $=3.3$ ), but were not overconditioned at parturition $(\mathrm{BCS}=3.5)$. Multiparous cows in the OVR group lost more BCS postpartum than did multiparous RES or CON cows. Primiparous cows lost similar amounts of BCS among dietary treatment groups postpartum. Addition of chopped wheat straw to CON diets prevented the large decrease in DMI prepartum in both primiparous and multiparous cows fed OVR. During the first 3 wk postpartum, DMI as a percentage of $\mathrm{BW}$ was lower for multiparous OVR cows than for multiparous RES cows. Prepartum diet effects did not carry over through the entire 8-wk lacta- tion period. Because of greater mobilization of body stores, OVR cows had greater milk fat percentage and greater $3.5 \%$ FCM yield during the first 3 wk postpartum. Multiparous cows assigned to OVR experienced a $55 \%$ decrease in energy balance and primiparous cows a $40 \%$ decrease in energy balance during the last $3 \mathrm{wk}$ before parturition, compared with CON or RES cows that had little change. Multiparous cows fed OVR had a greater contribution of energy from body energy reserves to milk energy output than either CON or RES cows. Even in the absence of overconditioning, a large change in DMI and energy balance prepartum for cows fed OVR influenced postpartum DMI and BCS loss, especially for multiparous cows.

\section{Blood Metabolites and Hormones}

Glucose. Blood glucose concentration was greater in OVR cows than in either CON or RES cows prepartum $(P \leq 0.02$; Figure 1A). Glucose concentration was not different between CON and RES cows $(P=$ 0.16). Parity also affected blood glucose; primiparous cows had greater glucose concentration prepartum compared with multiparous cows $(P<0.001)$. Within primiparous cows, blood glucose concentration did not differ among dietary treatments prepartum $(P \geq 0.15)$; however, glucose was greater in OVR cows compared with either CON or RES cows in the multiparous cow group (diet $\times$ parity, $P \leq 0.04$ ). Others have demonstrated that ad libitum feeding of higher energy diets prepartum resulted in higher blood glucose prepartum compared with restriction of intake (Dann et al., 2005, 2006; Douglas et al., 2006; Guo et al., 2007). This finding is unremarkable as it is known that diets containing highly fermentable starch-rich energy sources, such as corn grain, can result in increased blood glucose via propionate conversion in liver, especially for animals near maintenance requirements. Lactating cows responded to intraruminal infusion of propionate by decreasing their voluntary DMI (Oba and Allen, 2003a). The extent of reduction of DMI is related to blood glucose concentration that results from infusion of propionate and conversion to glucose in the liver (Oba and Allen, 2003b), which is also related to the amount needed by the body. If it is assumed that most of the blood glucose was derived from propionate in the OVR group, it is of interest that the negative effect on DMI was absent.

A large spike in blood glucose concentration occurred at parturition for all groups, but the increase was greater for OVR cows than for CON or RES cows $(P=0.01)$. Multiparous cows had larger glucose increases than primiparous cows $(P<0.001)$, but no interaction was found between parity and diet $(P=0.93)$. Holtenius et al. (2003) observed a similar difference in the spike 



Day relative to parturition

Figure 1. Covariate adjusted least squares means of serum glucose and insulin for multiparous (MultiP) and primiparous (PrimiP) Holsteins fed different diets prepartum. Pooled standard error bars are shown. Prepartum diet abbreviations: CON = controlled energy intake prepartum, fed for ad libitum intake and controlled energy intake to $100 \%$ of the NRC (2001) recommendation for energy for mature dry cows; OVR = cows overfed energy prepartum, diet fed for ad libitum intake to achieve an energy intake in excess (approximately 150\%) of the NRC (2001) recommendation for energy for mature dry cows; RES = restricted energy intake prepartum, OVR diet fed at restricted intake to $80 \%$ of the NRC (2001) recommendation for energy for mature dry cows. Multiparous cows were fed prepartum diets from dry off through parturition (approximately $65 \mathrm{~d}$ ) and primiparous cows were fed prepartum diets from $35 \mathrm{~d}$ before expected parturition through parturition. At parturition, all cows were fed the same lactation diet. (A) Prepartum: parity, $P<0.0001$; diet, $P=0.002$; day, $P=0.05$; parity $\times$ diet, $P=0.05$; other interactions of main effects $P>0.56$. Day of parturition: parity, $P=0.0002$; diet, $P=0.01$; parity $\times$ diet, $P=0.93$. Postpartum: parity, $P<$ 0.0001 ; diet, $P=0.56$; day, $P<0.0001$; other interactions of main effects $P>0.12$. (B) Prepartum: parity, $P=0.005$; diet, $P<0.0001$; day $P=0.002$; parity $\times$ diet $\times$ week, $P=0.06$; other interactions of main effects $P>0.47$. Day of parturition: parity, $P=0.05 ;$ diet and parity $\times$ diet, $P>0.39$. Postpartum: all effects and interactions, $P>0.18$.

of blood glucose on $\mathrm{d} 1$ relative to parturition between cows overfed energy prepartum and those restricted or fed to energy requirement. Roche (2007) reported a much larger spike in growth hormone concentration at calving in cows with restricted pasture allowance precalving compared with cows with full access to pasture. To further investigate the spike in glucose that occurred in the current study, time of parturition relative to the 
blood sample taken on d 0 was estimated for all cows as the difference between time of parturition recorded for each cow and the average time blood samples were taken daily $(1000 \mathrm{~h})$ for cows in maternity pens. This analysis revealed that for the CON cows, blood sampling occurred approximately $2 \mathrm{~h}$ after parturition, whereas for OVR and RES, it occurred approximately 2 and 4 h before parturition, respectively $(P=0.02)$. Furthermore, calving difficulty scores tended $(P=0.07)$ to be greater for primiparous cows in the CON group; however, calving difficulty score was not different between parity groups or among diets $(P \geq 0.20)$. Time of blood sampling and calving difficulty help to explain the effect of diet on blood glucose at parturition for $\mathrm{CON}$ primiparous cows, but multiparous OVR cows had a greater glucose spike than their counterparts. This observation deserves additional research to determine the effects of long-term overfeeding of energy prepartum on tissue responses to insulin, glucocorticoids, growth hormone, and catecholamines at calving.

In addition to possible differences in time of sampling and calving difficulty, another contributing factor to the observed increase in glucose may have been increased pyruvate carboxylase (PC) abundance and activity in liver around the time of parturition. In fasted rodents and diabetic subjects, $\mathrm{PC}$ is upregulated in response to glucose need and is allosterically regulated by acetylCo-A (Jitrapakdee and Wallace, 1999). In dairy cows, PC mRNA abundance is affected by physiological state (Greenfield et al., 2000) and is responsive to changes in nutritional status (Velez and Donkin, 2005). Janovick (2008) demonstrated that mRNA abundance of PC spiked at parturition relative to other time points pre- or postpartum. Perhaps the combination of the dramatic decline in DMI prepartum (Janovick and Drackley, 2010) plus increased supply of acetyl-CoA from fatty acid oxidation in cows of the OVR group increased the expression or activity of gluconeogenic enzymes such as PC, which could then have led to greater blood glucose at parturition. The nature of the signal for increased $\mathrm{PC}$ is not readily apparent. Although calf birth weight was not affected by diet in this study (Janovick and Drackley, 2010), it is conceivable that fetal cortisol production might have differed due to maternal nutrient supply.

Primiparous cows had greater blood glucose postpartum than multiparous cows $(P<0.001)$, but prepartum dietary effects did not carry over to lactation $(P=$ 0.56). Perhaps part of the difference between parity groups was a result of greater demand for milk yield and lactose production in multiparous cows, which, as expected, had greater milk and lactose yields than primiparous cows (Janovick and Drackley, 2010). Glucose concentration increased as lactation progressed (day, $P<0.001$ ) and cows returned to positive energy balance toward the end of the study period.

Insulin. The concentration of insulin prepartum was greater in primiparous cows than in multiparous cows $(P=0.005$; Figure 1B). As for blood glucose, the main effect of diet on insulin concentration prepartum was significant, where OVR cows had greater insulin than either CON or RES cows $(P<0.001)$. Insulin concentration prepartum did not differ between CON or RES cows $(P=0.78)$. A tendency was observed for a 3-way interaction of diet, parity, and day relative to parturition on insulin concentration prepartum $(P=$ 0.06 ), which was driven by a larger difference between OVR and CON or RES cows in the primiparous group than among treatments in multiparous cows and the decreasing difference between treatments in multiparous cows as parturition approached. Previous studies in our group (Dann et al., 2005, 2006; Douglas et al., 2006) have also demonstrated a greater concentration of insulin in blood from overfed cows prepartum compared with those of controlled or restricted intake prepartum; these results agree with those of others (Holtenius et al., 2003; Rabelo et al., 2005).

Insulin concentration was greater on the day of parturition for primiparous cows than for multiparous cows $(P=0.05)$. Effects of prepartum diet did not carry over to lactation and insulin was not different between parities $(P \geq 0.20)$, although CON cows tended to have greater insulin concentrations postpartum compared with OVR cows (5.27 and $4.21 \mathrm{mIU} / \mathrm{dL}, P=0.09)$. Rabelo et al. (2005) also studied both primiparous and multiparous cows but did not find differences in insulin concentration between parities or any interaction of parity with dietary treatment.

Decreased tissue responsiveness to insulin is part of the homeorhetic changes that take place during early lactation (Bauman, 2000). This insulin resistance ensures that mobilization of body stores can occur in support of lactation. To a certain extent, therefore, a degree of insulin resistance is needed to support higher milk production in early lactation. In our study, multiparous OVR cows lost more BCS than CON or RES cows even though DMI was not different among groups during the first 3 wk or first 8 wk of lactation (Janovick and Drackley, 2010). Perhaps as a result of greater mobilization of BCS in early lactation, OVR cows produced more 3.5\% FCM (Janovick and Drackley, 2010). Thus, altered responses to insulin in OVR could have promoted greater mobilization of NEFA (as discussed in a later section). On the other hand, altered responses to insulin could contribute to metabolic dysfunction in transition cows. In Dann et al. (2005), healthy cows had greater insulin concentrations postpartum than cows experiencing health problems postpartum. No dif- 


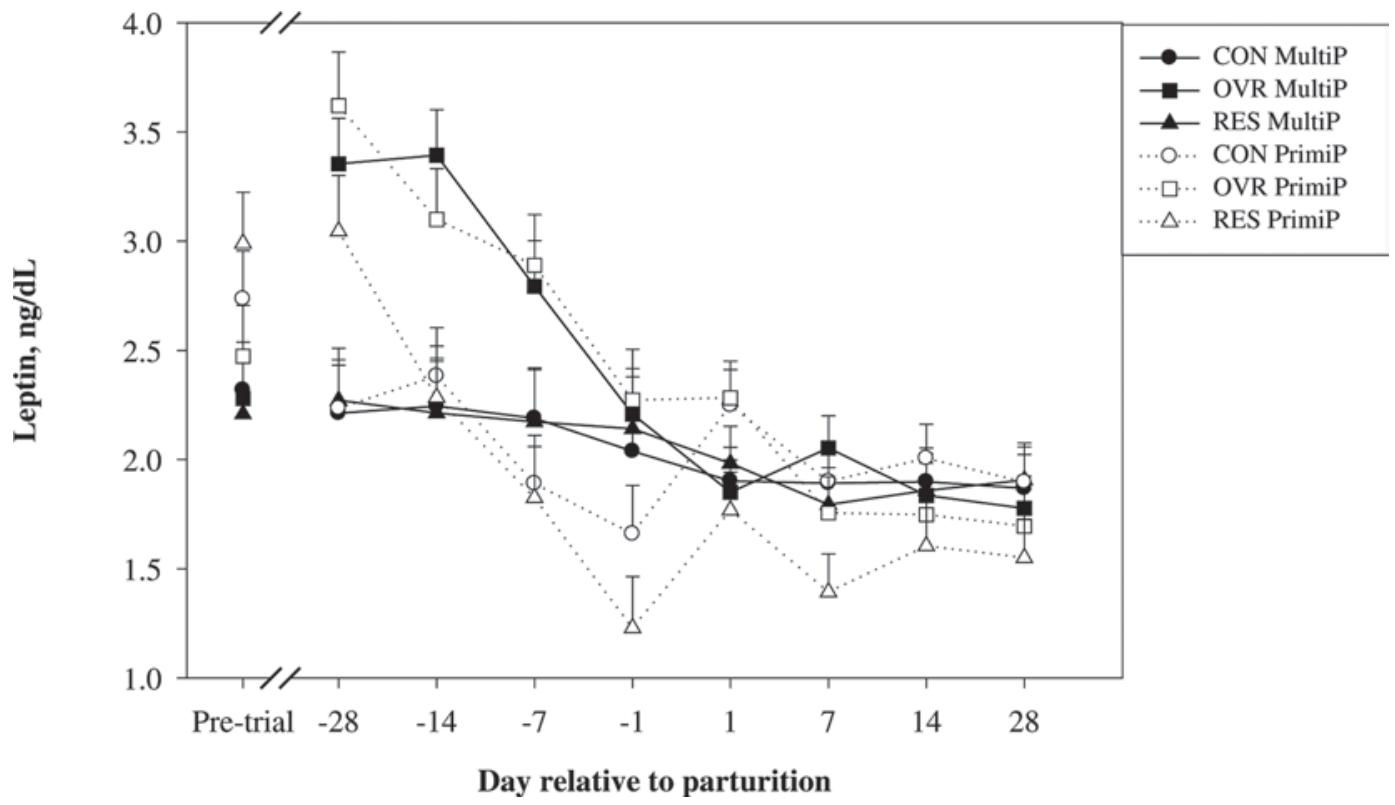

Figure 2. Covariate adjusted least squares means of serum leptin for multiparous (MultiP) and primiparous (PrimiP) Holsteins fed different diets prepartum. Pooled standard error bars are shown. Prepartum diet abbreviations: CON = controlled energy intake prepartum, fed for ad libitum intake and controlled energy intake to $100 \%$ of the NRC (2001) recommendation for energy for mature dry cows; OVR = cows overfed energy prepartum, diet fed for ad libitum intake to achieve an energy intake in excess (approximately 150\%) of the NRC (2001) recommendation for energy for mature dry cows; RES = restricted energy intake prepartum, OVR diet fed at restricted intake to $80 \%$ of the NRC (2001) recommendation for energy for mature dry cows. Multiparous cows were fed prepartum diets from dry off through parturition (approximately 65 d) and primiparous cows were fed prepartum diets from $35 \mathrm{~d}$ before expected parturition through parturition. At parturition, all cows were fed the same lactation diet. Prepartum: diet, $P<0.0001$; day, $P<0.0001$; diet $\times$ day, $P<0.0001$; parity $\times$ diet, $P=0.01$; other main effects and interactions, $P>0.15$. Postpartum: day, $P<0.0001$; parity $\times$ day, $P=0.0002$; other main effects and interactions, $P>0.28$.

ference in blood glucose was noted during the time period for which insulin was reported, perhaps suggesting that unhealthy cows had an altered response to insulin compared with healthy cows. A feed-deprivation model used to mimic negative energy balance in early lactation and induce fatty liver in dry cows resulted in altered glucose responses to insulin (Oikawa and Oetzel, 2006). In this model, fasted cows had lower insulin-stimulated blood glucose response than control cows and failed to increase glucose production over control cows despite a much lower insulin concentration during the fasting period. These data are complicated, however, by the decrease of glucose precursors in the absence of feed intake.

Overfeeding energy prepartum has been demonstrated to decrease glucose clearance rate in response to glucose challenge administered at 3 wk postpartum compared with cows in which intake was controlled or restricted prepartum (Holtenius et al., 2003). Although not measured directly, overfeeding energy prepartum seems to predispose cows to a greater degree of insulin resistance postpartum; several studies have reported greater insulin concentration without differences in blood glucose in cows overfed prepartum (Dann et al., 2005, 2006; Douglas et al., 2004, 2006; Rabelo et al., 2005). Too few data are available to make conclusions about primiparous cows, although our data support the possibility that overfeeding contributed to altered responses to insulin regardless of parity.

Leptin. Cows in the OVR group had greater serum leptin concentration prepartum than either CON or RES cows (Figure 2; $P<0.001$ ). Except in multiparous CON and RES cows, leptin concentration decreased as parturition approached (day, $P<0.001$ ) and was affected by an interaction between parity and prepartum $\operatorname{diet}(P \leq 0.01)$. In primiparous cows, leptin decreased as parturition approached regardless of dietary treatment group. Prepartum responses of leptin to feed restriction in the present study were similar to results reported for underfed ruminants and nonruminant species in other studies (Chilliard et al., 2001). Furthermore, as in the present study, sheep, goats, and cows overfed energy had greater plasma leptin than those that were underfed (Delavaud et al., 2000). Holtenius et al. (2003) also observed that prepartum feed intake affected leptin concentration prepartum.

The role of leptin in control of feed intake is questionable in dairy cows (Ingvartsen and Boisclair, 2001). Despite having higher circulating levels of leptin in blood, cows in the OVR group grossly over-consumed energy relative to their requirement (Janovick and Drackley, 2010). This phenomenon is similar to subjects with 
Table 1. Least squares means of plasma NEFA and serum BHBA for multiparous and primiparous Holsteins fed different diets prepartum ${ }^{1}$

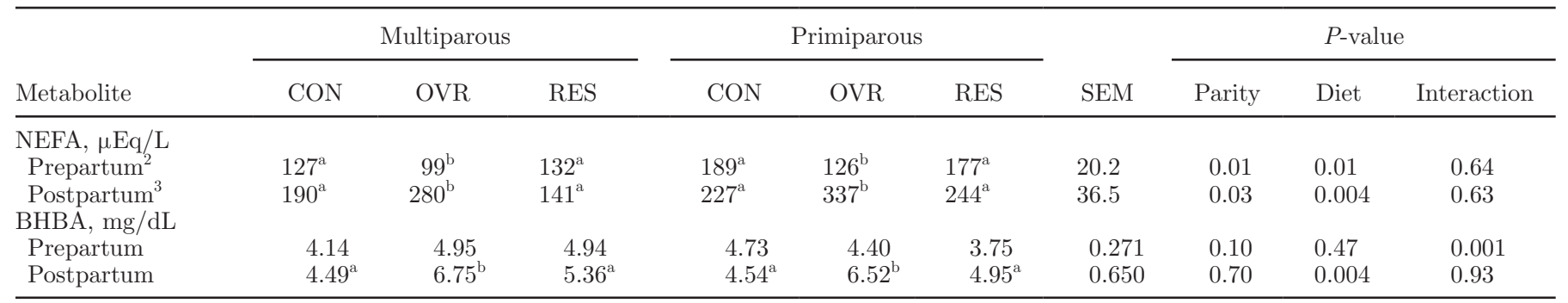

${ }^{\mathrm{a}, \mathrm{b}}$ Main effects of diet in the same row with different superscripts differ $(P \leq 0.05)$.

${ }^{1} \mathrm{CON}=$ controlled energy intake prepartum. This diet was fed for ad libitum intake and controlled energy intake to $100 \%$ of the NRC (2001) recommendation for energy for mature dry cows; OVR = cows overfed energy prepartum. This diet was fed for ad libitum intake to achieve an energy intake in excess (approximately 150\%) of the NRC (2001) recommendation for energy for mature dry cows; RES = restricted energy intake prepartum. The OVR diet was fed at restricted intake to achieve an energy intake of $80 \%$ of the NRC (2001) recommendation for energy for mature dry cows.

${ }^{2}$ Samples taken weekly from wk -5 to wk -1 relative to expected parturition.

${ }^{3}$ Samples taken weekly from wk 1 to wk 8 of lactation.

type II diabetes mellitus who have higher circulating leptin concentrations, yet do not respond with a reduction in food intake (Koerner et al., 2005).

Postpartum, dietary treatment did not affect leptin concentration $(P=0.28)$. An interaction of day and parity resulted from primiparous cows having more variable leptin concentrations than did multiparous cows. As reported by others (Delavaud et al., 2000; Chilliard et al., 2001; Ingvartsen and Boisclair, 2001), leptin was positively related to BCS $(P<0.0001)$ in the present study. Block et al. (2001) reported that circulating leptin decreased in early lactation when cows were in negative energy balance. Cows in the OVR group experienced a large change in energy balance prepartum and were in more negative energy balance postpartum compared with other groups (Janovick and Drackley, 2010); however, leptin concentration was not related to severity of negative energy balance postpartum.

$\boldsymbol{N E F A}$. The weekly concentration of NEFA was lower in OVR cows compared with CON or RES cows prepartum (Table $1 ; P=0.01$ ), likely as a result of the high energy intake and high insulin concentration for OVR cows. Primiparous cows had greater weekly NEFA concentration than multiparous cows prepartum $(P=0.01)$. In the $10 \mathrm{~d}$ before parturition, primiparous cows tended $(P=0.09)$ to have greater NEFA concentrations compared with multiparous cows (Figure 3A), but effects of dietary treatment were not evident $(P=$ 0.91). Restricting DMI resulted in higher NEFA prepartum in earlier studies (Murondoti et al., 2004; Dann et al., 2005, 2006; Roche et al., 2005; Douglas et al., 2006; Roche, 2007). In addition, a higher energy density diet resulted in lower NEFA compared with feeding a diet with moderate energy density prepartum (Rabelo et al., 2005). In other studies, however, prepartum plane of energy intake had no effect on prepartum NEFA (Rukkwamsuk et al., 1999; Holtenius et al., 2003; Guo et al., 2007).

At parturition, OVR cows tended to have greater NEFA concentrations than CON or RES cows $(P \leq$ $0.06)$, regardless of parity $(P=0.40)$. Postpartum, weekly concentrations of NEFA were greater in primiparous than in multiparous cows (Table $1 ; P=0.03$ ) and greater in OVR than in CON or RES cows $(P$ $\leq 0.01$ ). The concentration of NEFA remained greater during the first 2 wk postpartum in the primiparous OVR group compared with other diet and parity combinations (day $\times$ diet, $P=0.04$ ). Daily concentrations of NEFA were greater in OVR cows than in CON or RES cows postpartum (Figure 3B; $P=0.001$ ) regardless of parity $(P=0.61)$. Day relative to parturition affected daily NEFA concentration postpartum $(P<$ 0.001 ) and an interaction between day and parity also occurred. This interaction was influenced by the tendency for larger changes in multiparous groups after parturition (largely influenced by OVR cows) compared with primiparous cows $(P=0.002)$. Large changes were observed in OVR multiparous cows, whereas smaller changes were observed in all other parity and dietary treatment groups.

Large decreases in prepartum DMI have been related to greater NEFA postpartum regardless of parity (Grummer et al., 2004). Preventing a decrease in DMI prepartum failed to attenuate NEFA postpartum in cows force-fed refusals through a ruminal cannula (Bertics et al., 1992). In contrast, several studies in our group (Dann et al., 2005, 2006; Douglas et al., 2006) and by others (Rukkwamsuk et al., 1999; Holtenius et al., 2003; Guo et al., 2007) have demonstrated that a higher plane of energy intake prepartum results in larger 

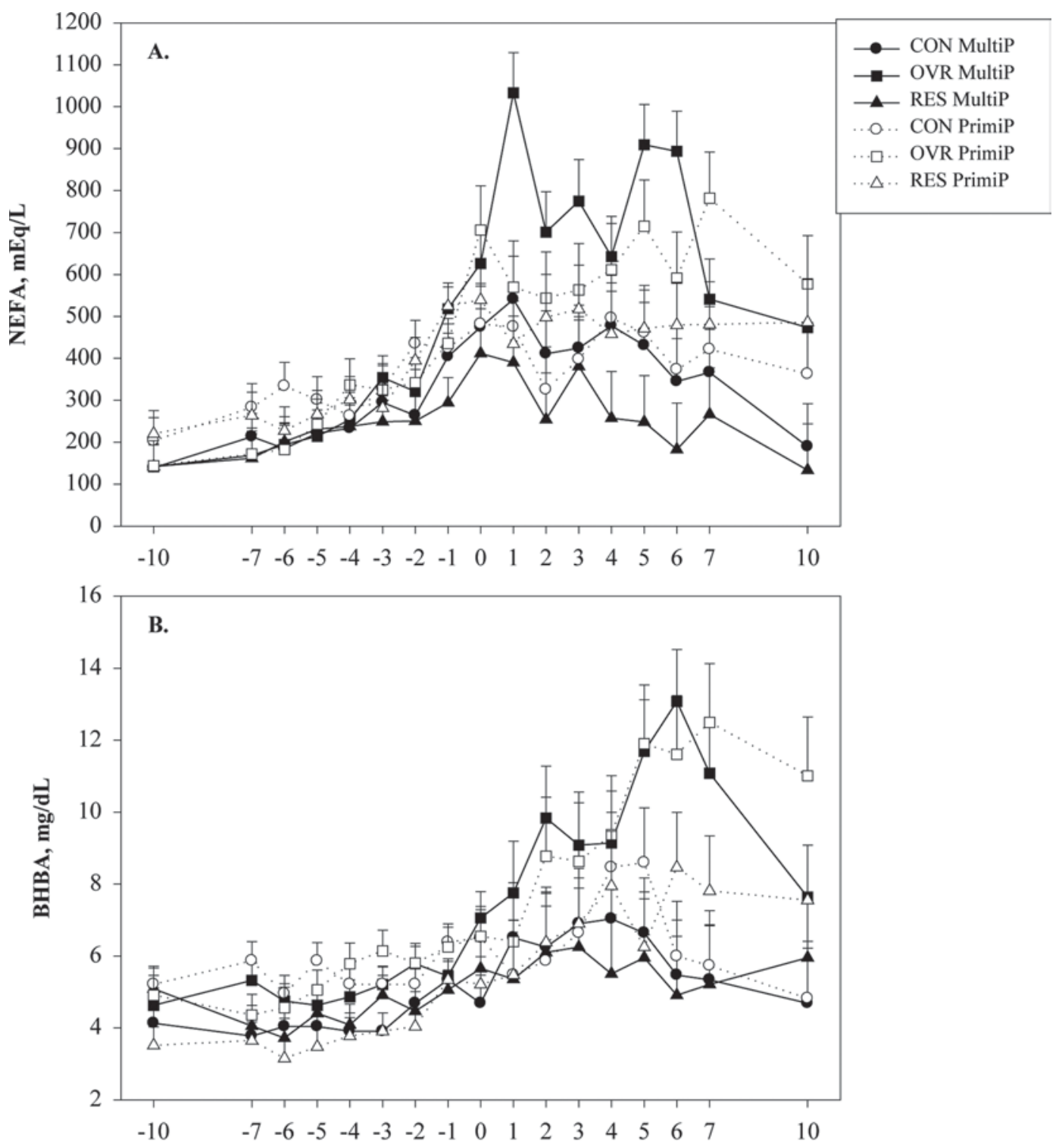

Day relative to parturition

Figure 3. Covariate adjusted least squares means of plasma NEFA and serum BHBA for multiparous (MultiP) and primiparous (PrimiP) Holsteins fed different diets prepartum. Pooled standard error bars are shown. Prepartum diet abbreviations: CON $=$ controlled energy intake prepartum, fed for ad libitum intake and controlled energy intake to $100 \%$ of the NRC (2001) recommendation for energy for mature dry cows; OVR = cows overfed energy prepartum, diet fed for ad libitum intake to achieve an energy intake in excess (approximately 150\%) of the NRC (2001) recommendation for energy for mature dry cows; RES = restricted energy intake prepartum, OVR diet fed at restricted intake to $80 \%$ of the NRC (2001) recommendation for energy for mature dry cows. Multiparous cows were fed prepartum diets from dry off through parturition (approximately $65 \mathrm{~d}$ ) and primiparous cows were fed prepartum diets from $35 \mathrm{~d}$ before expected parturition through parturition. At parturition, all cows were fed the same lactation diet. (A) Prepartum: parity, $P=0.09$; diet, $P=0.91$; day, $P<0.0001$; other interactions of main effects $P>0.23$. Day of parturition: diet, $P=0.10$; day and interaction with diet, $P>0.40$. Postpartum: parity, $P=0.79$; diet, $P=0.001 ;$ day, $P=$ 0.0002 ; parity $\times$ day, $P=0.003$; other interactions of main effects $P>0.12$. (B) Prepartum: parity, $P=0.33$; diet, $P=0.03$; day, $P<0.0001$; parity $\times$ diet, $P=0.07$; other interactions of main effects, $P>0.24$. Day of parturition: parity, $P=0.66 ;$ diet, $P=0.18 ;$ parity $\times$ diet, $P>0.25$. Postpartum: parity, $P=0.48$; diet, $P=0.002$; day, $P=0.07$; diet $\times$ day, $P=0.07$; other interactions of main effects, $P>0.77$.

decreases in DMI postpartum and higher circulating NEFA within the first 4 wk postpartum compared with cows having controlled or restricted intake prepartum, similar to the present study (Janovick and Drackley,
2010). In these scenarios, it seems that even if there may be a tendency to increase NEFA prepartum in cows with controlled or restricted DMI, these cows are still better equipped to cope with NEFA as a metabolic 


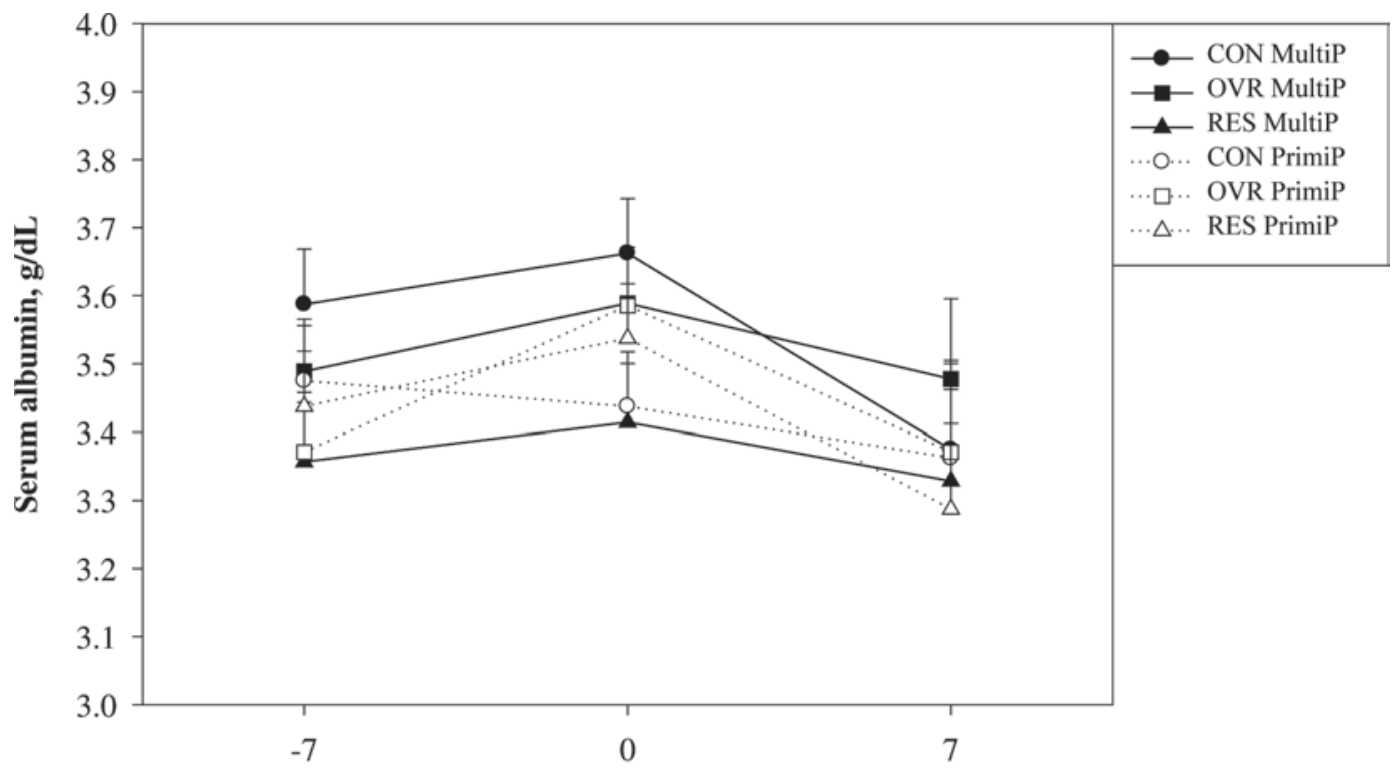

Day relative to parturition

Figure 4. Least squares means of plasma albumin for multiparous (MultiP) and primiparous (PrimiP) Holsteins fed different diets prepartum. Pooled standard error bars are shown. Prepartum diet abbreviations: CON = controlled energy intake prepartum, fed for ad libitum intake and controlled energy intake to $100 \%$ of the NRC (2001) recommendation for energy for mature dry cows; OVR = cows overfed energy prepartum, diet fed for ad libitum intake to achieve an energy intake in excess (approximately 150\%) of the NRC (2001) recommendation for energy for mature dry cows; RES = restricted energy intake prepartum, OVR diet fed at restricted intake to 80\% of the NRC (2001) recommendation for energy for mature dry cows. Multiparous cows were fed prepartum diets from dry off through parturition (approximately $65 \mathrm{~d}$ ) and primiparous cows were fed prepartum diets from $35 \mathrm{~d}$ before expected parturition through parturition. At parturition, all cows were fed the same lactation diet. Prepartum: main effects and interactions, $P>0.25$. Day of parturition: diet $\times$ parity, $P=0.10$; main effects, $P>0.40$. Postpartum: main effects and interactions, $P>0.61$.

fuel after parturition, as postulated by Friggens et al. (2004). Similar responses were reported by Roche et al. (2005) and Roche (2007).

The greater NEFA concentrations for cows fed OVR correspond to the greater negative energy balance in those cows (Janovick and Drackley, 2010) that resulted primarily from the increased FCM yield. In turn, however, the greater calculated negative energy balance for OVR cows largely resulted from greater milk fat production $(1.72 \mathrm{~kg} / \mathrm{d}$ vs. 1.16 and $1.13 \mathrm{~kg} / \mathrm{d}$ for CON and RES cows, respectively, during the first $3 \mathrm{wk}$ of lactation). Lactose production was not affected by diet $(1.59,1.66$, and $1.41 \mathrm{~kg} / \mathrm{d}$ for CON, OVR, and RES); thus, it is difficult to argue that mobilization of body lipid reserves was stimulated by a greater negative energy balance from greater milk production per se. Rather, body lipid mobilization, as reflected by NEFA, seems to be stimulated by prepartum overfeeding, which in turn increases milk fat content and production, leading to greater calculated negative energy balance. Similar findings were reported in cows offered different amounts of pasture prepartum (Roche, 2007; Roche et al., 2005).

Other studies have reported no main effect of energy on NEFA for primiparous or multiparous cows fed high or low energy diets prepartum, although multiparous cows had higher NEFA concentrations postpartum than primiparous cows (VandeHaar et al., 1999). A similar trend in NEFA concentration between parity groups was reported by Rabelo et al. (2005). In this case, a higher energy diet prepartum resulted in lower NEFA postpartum compared with a moderate energy diet. Increased NEFA in multiparous cows was most likely associated with more mobilization of adipose TAG to support greater milk yield and component demands for energy compared with primiparous cows.

$\boldsymbol{B} \boldsymbol{H} \boldsymbol{B} \boldsymbol{A}$. Weekly plasma BHBA concentration was not affected by diet or parity prepartum, but an interaction between these 2 main effects was observed (Table 1; $P=0.001$ ). This interaction resulted largely from primiparous cows in the RES group having lower BHBA concentration than multiparous cows in this group $(P<0.01)$. Multiparous cows in the CON group had lower weekly BHBA concentrations than cows in the OVR or RES group $(P \leq 0.05)$. On the other hand, primiparous cows in the CON group had greater weekly BHBA concentration prepartum than cows in the OVR group $(P=0.02)$. Daily concentration of BHBA in plasma was greater in OVR than in RES cows prepartum (Figure 3B; $P=0.01$ ) and tended to increase for 

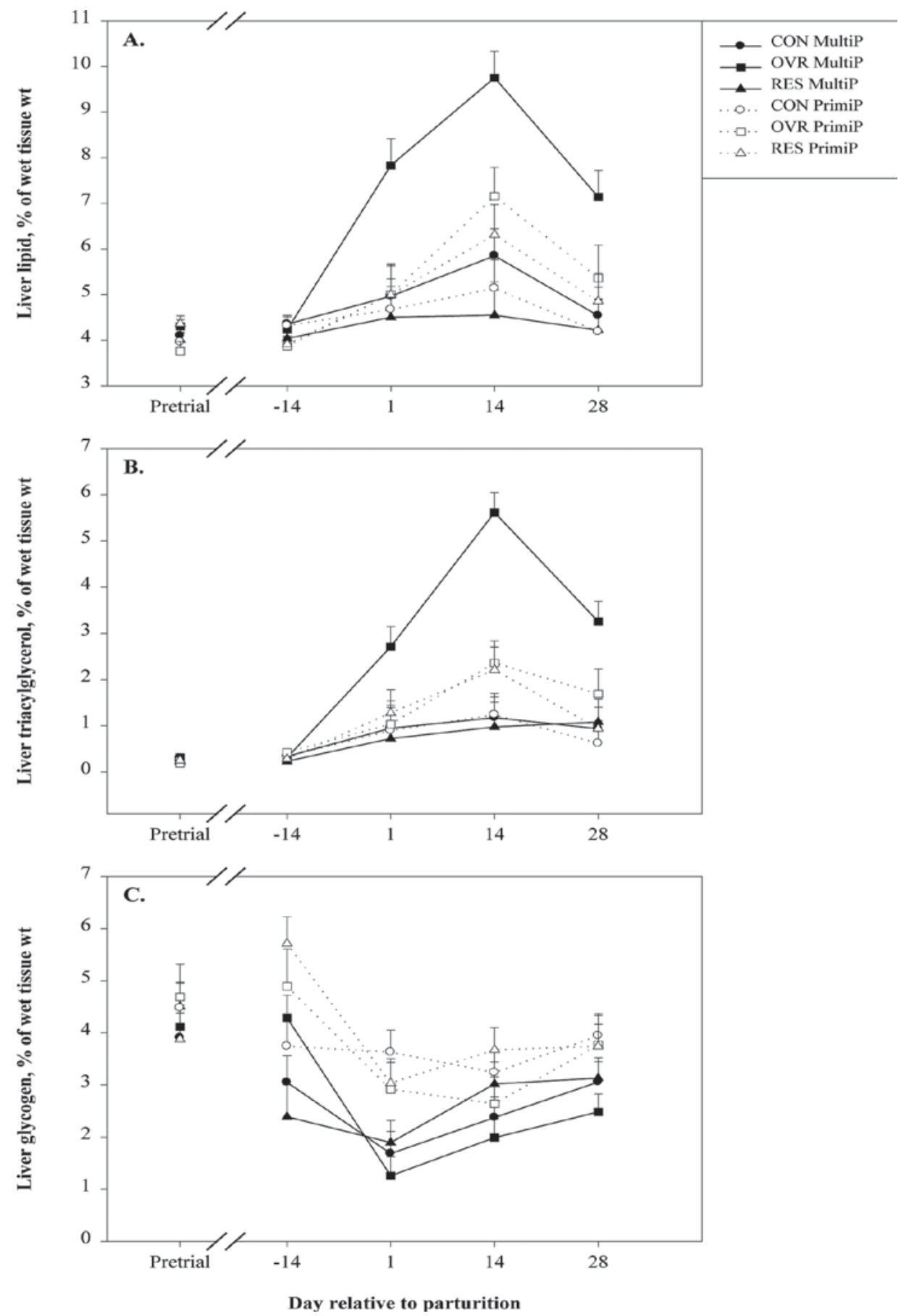

Figure 5. Least squares means of liver total lipid, triacylglycerol, and glycogen concentrations (percent of wet tissue weight) for multiparous (MultiP) and primiparous (PrimiP) Holsteins fed different diets prepartum. Pooled standard error bars are shown. Prepartum diet abbreviations: $\mathrm{CON}=$ controlled energy intake prepartum, fed for ad libitum intake and controlled energy intake to 100\% of the NRC (2001) recommendation for energy for mature dry cows; OVR = cows overfed energy prepartum, diet fed for ad libitum intake to achieve an energy intake in excess (approximately 150\%) of the NRC (2001) recommendation for energy for mature dry cows; RES = restricted energy intake prepartum, OVR diet fed at restricted intake to $80 \%$ of the NRC (2001) recommendation for energy for mature dry cows. Multiparous cows were fed prepartum diets from dry off through parturition (approximately $65 \mathrm{~d}$ ) and primiparous cows were fed prepartum diets from $35 \mathrm{~d}$ before expected parturition through parturition. At parturition, all cows were fed the same lactation diet. (A) Prepartum: all main effects and interactions, $P>$ 0.11. Postpartum: parity, $P=0.25$; diet, $P=0.0001$; day, $P<0.0001$; parity $\times$ diet, $P=0.02$; other interactions of main effects, $P>0.21$. (B) Prepartum: day, $P=0.05$; all other main effects and interactions, $P>0.11$. Postpartum: parity, $P=0.15$; diet, $P=0.0003$; day, $P<0.0001$; parity $\times$ diet, $P=0.01$; diet $\times$ day, $P=0.01$; parity $\times$ day, $P=0.39$; parity $\times$ diet $\times$ day, $P=0.06$. (C) Prepartum: parity, $P<0.0001$; diet, $P=0.11$; day, $P<0.0001$; all other main effects and interactions, $P>0.36$. Postpartum: parity, $P=0.004 ;$ diet, $P=0.12$; day, $P=0.46$; parity $\times$ day, $P=0.05$; parity $\times$ diet $\times$ day, $P=0.03$; other interactions of main effects, $P>0.48$. 
all groups as parturition approached (day, $P<0.001$ ). An interaction between diet and parity tended $(P=$ $0.06)$ to affect daily BHBA concentration prepartum. Whereas multiparous cow groups demonstrated similar trends prepartum, primiparous cows in the RES group had lower daily BHBA concentration prepartum compared with CON or OVR cows in this parity group ( $P$ $\leq 0.01)$.

Others have noted that prepartum energy intake did not affect BHBA prepartum even in cows with restricted intake (Holtenius et al., 2003; Dann et al., 2005; Douglas et al., 2006; Guo et al., 2007). On the other hand, Dann et al. (2006) reported that overfeeding energy during the far-off dry period, regardless of energy intake in the close-up period, resulted in higher BHBA compared with controlling energy intake in the far-off period. This effect was larger in the last $7 \mathrm{~d}$ before parturition regardless of close-up feeding strategy. Roche (2007) and Roche et al. (2005) reported that restricted pasture access during the last $17 \mathrm{~d}$ prepartum increased prepartal BHBA concentrations. Length of feeding a high energy diet prepartum (Mashek and Beede, 2001), feeding fat compared with a high grain diet (Douglas et al., 2004), feeding a different level of NFC in the diet (Minor et al., 1998), and moderate compared with high energy density diets fed prepartum (Rabelo et al., 2005 ) did not affect BHBA prepartum. Unlike the present study, parity differences in BHBA prepartum were not observed by Rabelo et al. (2005).

No treatment or parity effects were observed for BHBA at parturition $(P \geq 0.17)$. Cows in the OVR group had greater weekly BHBA concentrations postpartum than either CON or RES cows (Table 1; $P \leq$ 0.02). Like NEFA, weekly BHBA concentrations remained greater in the primiparous OVR group during the first 2 wk postpartum compared with the other treatment and parity groups (diet $\times$ day, $P=0.02$ ). Daily concentrations of BHBA were greater during the first $10 \mathrm{~d}$ postpartum for OVR compared with either CON or RES cows (Figure 3B; $P=0.002$ ) regardless of parity $(P=0.48)$. As NEFA are mobilized and oxidized by the liver, a larger flux of ketone body production is expected. Therefore, postpartum results are not unexpected when all variables are considered collectively.

Increased production of ketones is not necessarily detrimental to cow health because oxidation of NEFA accompanied by ketone production provides an alternate water-soluble fuel to tissues such as skeletal muscle. In fact, lower rates of TAG esterification and greater rates of NEFA oxidation in liver postpartum have been observed even though BHBA was higher when fat (Grum et al., 1996) or L-carnitine (Carlson et al., 2007) were fed prepartum. In the present study, however, as in others (Rukkwamsuk et al., 1999; Rabelo et al., 2005;
Dann et al., 2006; Douglas et al., 2006), greater BHBA production postpartum was not accompanied by lower total lipid or TAG accumulation in liver postpartum, suggesting that NEFA oxidation was not able to outpace esterification. Feeding a higher energy density diet prepartum resulted in lower BHBA postpartum compared with feeding a moderate energy density diet prepartum (Rabelo et al., 2005). An interaction with parity group occurred in that study likely as a result of level of postpartum dietary energy density.

Albumin. Plasma albumin concentration was not affected by diet or parity at $7 \mathrm{~d}$ prepartum (Figure $4 ; P \geq$ $0.25)$. Likewise, albumin concentration was not affected by prepartum diet or parity at parturition or on $\mathrm{d} 7$ postpartum $(P \geq 0.10)$. A tendency for an interaction between parity and diet occurred on $\mathrm{d}-7$ and 0 relative to parturition as a result of a tendency $(P \leq 0.08)$ for multiparous $\mathrm{CON}$ cows to have higher albumin on $\mathrm{d}-7$ and 0 relative to parturition compared with multiparous RES cows. Lack of effect among dietary treatment groups indicates that metabolizable protein supply likely was sufficient among all groups. Albumin is used as an indicator of liver function in many species and low concentrations have been linked to fatty liver disease in dairy cows (Bobe et al., 2004). Even though overfed cows accumulated more liver lipid postpartum than control or restricted cows, prepartum energy intake did not affect plasma albumin concentrations in Dann et al. (2006), who reported clinical chemistry panels $10 \mathrm{~d}$ on either side of parturition. Bionaz et al. (2007) reported that cows with higher circulating paraoxonase in blood postpartum also had higher circulating albumin during the first $21 \mathrm{~d}$ postpartum. Like albumin, paraoxonase is positively related to liver function. More data are needed to make stronger conclusions on how prepartum energy intake relates to albumin and liver health.

\section{Liver Composition}

Liver total lipid as a percentage of wet tissue weight was not affected by dietary treatment group or parity prepartum (Figure 5A; $P \geq 0.22$ ). Postpartum, cows in the OVR group had greater hepatic total lipid than CON or RES cows $(P \leq 0.001)$ regardless of parity $(P$ $=0.24)$. Interestingly, primiparous cows in the RES group had greater liver total lipid postpartum compared with CON cows in the same parity, whereas multiparous cows in the RES group had lower total lipid concentration compared with CON cows (diet $x$ parity, $P<0.001$ ). Like total lipid concentration, TAG concentration in liver as a percentage of wet tissue weight was not affected by diet prepartum (Figure 5B; $P=0.47)$. Postpartum, cows in the OVR group had greater TAG concentration in their liver compared with 
CON or RES cows $(P \leq 0.001)$ regardless of parity $(P$ $=0.15$ ). Primiparous cows in the CON group had lower liver TAG concentration than either OVR or RES cows in the same parity, which explained the diet by parity interaction postpartum $(P=0.01)$. Additionally, large differences between OVR and either CON or RES cows in the multiparous group occurred $(P<0.001)$ compared with those differences observed among dietary groups in primiparous cows $(P \geq 0.14)$. Both liver total lipid and TAG concentrations in liver peaked at d 14 relative to parturition.

With the exception of individual cows, postpartum liver lipid and TAG accumulation among treatment groups in this study did not classify cows as having severe fatty liver (Gaal et al., 1983; Bobe et al., 2004). Multiparous cows in the OVR group could be classified on the basis of TAG data as having a moderate degree of fatty liver. Using the same scale, other treatment groups were classified as having mild fatty liver. From previous work, we expected that primiparous cows would have less fatty infiltration of liver than multiparous cows (Grummer et al., 2004). Even so, in the case of individual animals, some OVR primiparous cows were found to have total lipid and TAG concentrations in liver that approached that of multiparous cows.

Prepartal liver glycogen as a percentage of wet tissue weight was not affected by prepartum diet (Figure 5C; $P=0.11$ ); however, primiparous cows had greater liver glycogen than multiparous cows $(P<0.001)$. Postpartum concentration of liver glycogen was not affected by prepartum diet $(P=0.12)$ but remained greater in primiparous cows than in multiparous cows $(P<$ 0.001). For all groups, liver glycogen reached a nadir on d 1 postpartum and was replenished as lactation progressed. A 3-way interaction affected liver glycogen concentration postpartum, which seemed to be largely a result of CON primiparous cows exhibiting the least change overall postpartum compared with other diet and parity combinations $(P=0.03)$. Parity differences could have been partially attributed to the lower milk yield and thus relatively lower glucose demand of primiparous cows. Additionally, multiparous cows had greater total lipid and TAG accumulation in liver postpartum compared with primiparous cows, further reducing glycogen as a proportion of wet tissue weight.

Fatty liver is a multifactorial disorder in dairy cows (Bobe et al., 2004). Although not all mechanisms are understood clearly, several factors associated with overnutrition prepartum are related to fatty liver and associated metabolic dysfunction postpartum. Preventing a decrease in DMI prepartum by force-feeding refusals was successful in reducing liver total lipid and TAG accumulation compared with cows allowed to undergo a natural drop in their DMI prepartum (Bertics and
Grummer, 1999). Other research has noted increased liver total lipid or TAG accumulation postpartum when cows were fed diets to allow overconsumption of energy prepartum compared with restricting intake (Dann et al., 2005; Douglas et al., 2006). These effects were more pronounced when cows were allowed to over-consume energy in the far-off period, followed by feed restriction in the close-up period (Dann et al., 2006). On the other hand, Rabelo et al. (2005) did not observe an effect of prepartum dietary energy density on TAG accumulation postpartum in multiparous or primiparous cows despite the tendency for higher energy density diets to reduce NEFA and BHBA postpartum. Perhaps the small difference in energy density between prepartum diets $(0.10 \mathrm{Mcal} / \mathrm{kg})$ and the greater $\mathrm{NE}_{\mathrm{L}}$ density than NRC (2001) requirements for both groups precluded differences between diets for liver composition.

Overfeeding energy to cows prepartum resulted in greater esterification of fatty acids in adipose tissue prepartum, less response of adipose tissue to insulin postpartum, and greater accumulation of TAG in liver compared with cows with restricted intake prepartum (Rukkwamsuk et al., 1999). Furthermore, the presence of BHBA in tissue culture media increased lipolysis in adipose tissue from overfed cows following parturition (Rukkwamsuk et al., 1998). Adipose tissue also was less sensitive to inhibition of lipolysis by glucose in vitro $1 \mathrm{wk}$ before parturition compared with tissue from restricted cows. As a result, a much larger release of NEFA and greater production of BHBA were noted for overfed cows postpartum. Liver processes such as $\beta$-oxidation and Krebs cycle capacity postpartum were reduced by overfeeding energy prepartum (Murondoti et al., 2004), which those authors suggested might contribute to accumulation of TAG in liver tissue. Mixed results related to level of intake prepartum have been reported for $\beta$-oxidation via carnitine palmitoyltransferase-1 (CPT1) sensitivity to malonyl-CoA inhibition. On one hand, plane of intake did not change sensitivity of CPT-1 either prepartum or postpartum (Dann and Drackley, 2005). On the other hand, restricting intake to $80 \%$ of energy requirements prepartum resulted in increased total CPT activity $1 \mathrm{~d}$ postpartum compared with cows allowed to over-consume energy (Douglas et al., 2006), which should have led to increased $\beta$-oxidation. Perhaps state of energy balance prepartum has more profound effects on capacity for $\beta$-oxidation immediately postpartum.

In nonruminants, nonspecific inflammation is linked with nonalcoholic fatty liver disease in diabetic or obese subjects (Jin et al., 2005; Desvergne et al., 2006). This mechanism has not been well investigated in periparturient dairy cows or in the context of plane of energy intake prepartum; however, evidence is emerging for 
Table 2. Frequency of occurrence of health problems and twinning in multiparous and primiparous Holstein cows fed different diets prepartum $^{1}$

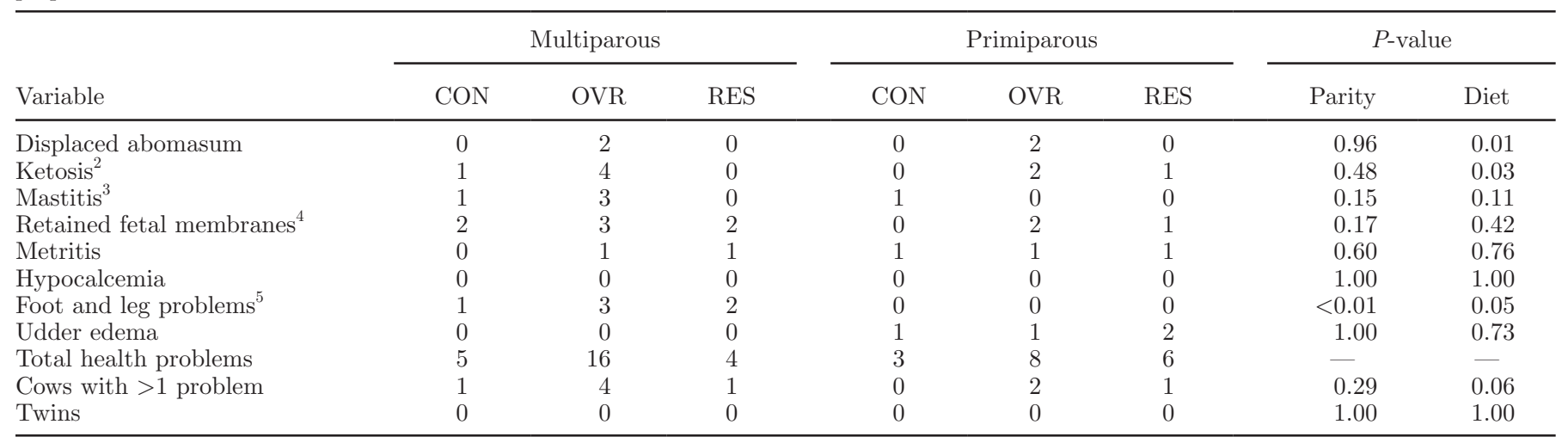

${ }^{1} \mathrm{CON}=$ controlled energy intake prepartum. This diet was fed for ad libitum intake and controlled energy intake to $100 \%$ of the NRC (2001) recommendation for energy for mature dry cows; OVR $=$ cows overfed energy prepartum. This diet was fed for ad libitum intake to achieve an energy intake in excess (approximately 150\%) of the NRC (2001) recommendation for energy for mature dry cows; RES = restricted energy intake prepartum. The OVR diet was fed at restricted intake to achieve an energy intake of $80 \%$ of the NRC (2001) recommendation for energy for mature dry cows.

${ }^{2}$ Defined as cows having moderate or larger ketones in urine as detected using a reagent strip and treated by veterinarians with oral propylene glycol or intravenous dextrose.

${ }^{3}$ Clinical cases of mastitis diagnosed and treated by farm staff or veterinarians.

${ }^{4}$ Defined as fetal membranes retained $>24 \mathrm{~h}$ postpartum.

${ }^{5}$ Problems included abscess, ulcer, digital dermatitis, and hock trauma.

a link between a nonspecific inflammatory response and fatty liver or metabolic disease. The mRNA for the proinflammatory cytokine tumor necrosis factor- $\alpha$ increased around parturition, which indicated the presence of nonspecific inflammation (Loor et al., 2005). Janovick (2008) demonstrated that cows overfed energy prepartum had increased expression of IL-1 $\beta$ mRNA in liver tissue, which was related to liver total lipid accumulation postpartum. The scope of the present study does not allow conclusions to be drawn about a link between nonspecific inflammation and fatty liver; however, data suggesting the interaction between fatty liver and insulin resistance are compelling. Further investigation into the interaction between prepartum energy intake, nonspecific inflammation, and fatty liver disease in dairy cows is warranted.

\section{Health}

Health-related problems that occurred during the trial are summarized in Table 2. Frequency of displaced abomasum and ketosis was greater $(P \leq 0.03)$ in cows in the OVR group regardless of parity $(P \geq 0.48)$. Multiparous cows had more foot and leg related problems than primiparous cows $(P<0.01)$. For both parity groups, frequency of mastitis, retained fetal membranes, metritis, and hypocalcemia were not affected by prepartum dietary treatment $(P \geq 0.11)$. Udder edema occurred only in primiparous cows, but was not affected by diet $(P=0.73)$. No twins were born to cows in either parity group during this study. Other studies in our group (Dann et al., 2006; Douglas et al., 2004, 2006) and by others (Boisclair et al., 1987; VandeHaar et al., 1999), although using relatively small numbers of cows per treatment group as in the present study, have also demonstrated that overfeeding energy prepartum results in a greater number of health problems postpartum.

\section{General Discussion}

The effect of prepartum energy intake on metabolic profiles pre- and postpartum was strikingly similar between parity groups. Furthermore, incidence of health problems was greater for cows that were overfed energy prepartum, regardless of parity group. Therefore, dietary management strategies that prevent mixed groups of cows from grossly over-consuming energy seem warranted for promoting animal health and favorable liver function postpartum. Additionally, because of little difference in metabolic profiles between cows with controlled energy intake and cows with restricted intake, it is reasonable to conclude that controlling energy intake via high-bulk diets and restricting energy intake prepartum are similar in a metabolic context.

Body condition score of cows in this study was not different among treatment groups within parities before the study began (Janovick and Drackley, 2010), although a larger range of prepartum BCS was observed in multiparous than in primiparous cows. Because primiparous cows were more uniform in BCS and carried 
more BCS than multiparous cows prepartum (3.35 and 3.01 , respectively), it would be interesting to determine if primiparous cows with lower BCS would have similar metabolic profiles when fed at different levels of energy intake prepartum.

\section{CONCLUSIONS}

Overfed cows experienced hyperglycemia, hyperinsulinemia, and greater circulating leptin prepartum, followed by a period of greater hyperlipidemia and ketone body production postpartum compared with cows having controlled or restricted intake prepartum. In overfed cows, this was coupled with greater liver total lipid and TAG accumulation and greater incidence of metabolic disorders. Together, these results indicate greater mobilization of adipose tissue TAG postpartum and perhaps less sensitivity of adipose tissue to insulin. We provide evidence to support the importance of controlling energy intake prepartum, whether by use of high-bulk diets or by limiting feed intake, to prevent metabolic dysfunction postpartum. Our evidence is consistent with the hypothesis that the prepartum "overnutrition syndrome" may aggravate insulin resistance that occurs postpartum, contributing to greater mobilization of adipose TAG from body stores and subsequent development of metabolic disorders.

\section{ACKNOWLEDGMENTS}

The authors greatly appreciate the assistance given by the staff at the University of Illinois Dairy Research Unit with animal care and data collection. The authors also extend thanks to D. Carlson, R. Ebert, E. French, K. Morgan, K. Moyes, N. Litherland, D. Rincker, and J. Stamey (all of the Department of Animal Sciences, University of Illinois, Urbana) for assistance with sample collection, surgical procedures, and laboratory procedures.

\section{REFERENCES}

Agenäs, S., E. Burstedt, and K. Holtenius. 2003. Effects of feeding intensity during the dry period. 1. Feed intake, body weight, and milk production. J. Dairy Sci. 86:870-882.

Bauman, D. E. 2000. Regulation of nutrient partitioning during lactation: Homeostasis and homeorhesis revisited. Pages 311-328 in Ruminant Physiology. P. B. Cronje, ed. CABI Publishing, Cambridge, MA.

Beever, D. E. 2006. The impact of controlled nutrition during the dry period on dairy cow health, fertility and performance. Anim. Reprod. Sci. 96:212-226.

Bertics, S. J., and R. R. Grummer. 1999. Effects of fat and methionine hydroxy analog on prevention or alleviation of fatty liver induced by feed restriction. J. Dairy Sci. 82:2731-2736.

Bertics, S. J., R. R. Grummer, C. Cadorniga-Valino, and E. E. Stoddard. 1992. Effect of prepartum dry matter intake on liver triglyc- eride concentration and early lactation. J. Dairy Sci. 75:19141922.

Bionaz, M., E. Trevisi, L. Calamari, F. Librandi, A. Ferrari, and G. Bertoni. 2007. Plasma paraoxonase, health, inflammatory conditions, and liver function in transition dairy cows. J. Dairy Sci. 90:1740-1750.

Block, S. S., W. R. Butler, R. A. Ehrhardt, A. W. Bell, M. E. Van Amburgh, and Y. R. Boisclair. 2001. Decreased concentration of plasma leptin in periparturient dairy cows is caused by negative energy balance. J. Endocrinol. 171:339-348.

Bobe, G., J. W. Young, and D. C. Beitz. 2004. Invited review: Pathology, etiology, prevention, and treatment of fatty liver in dairy cows. J. Dairy Sci. 87:3105-3124.

Boisclair, Y., D. G. Grieve, O. B. Allen, and R. A. Curtis. 1987. Effect of prepartum energy, body condition, and sodium bicarbonate on health and blood metabolites of Holstein cows in early lactation. J. Dairy Sci. 70:2280-2290.

Carlson, D. B., J. W. McFadden, A. D'Angelo, J. C. Woodworth and J. K. Drackley. 2007. Dietary L-carnitine affects periparturient nutrient metabolism and lactation in multiparous cows. J. Dairy Sci. 90:3422-3441.

Chilliard, Y., M. Bonnet, C. Delavaud, Y. Faulconnier, C. Leroux, J. Djiane, and F. Bocquier. 2001. Leptin in ruminants. Gene expression in adipose tissue and mammary gland, and regulation of plasma concentration. Domest. Anim. Endocrinol. 21:271-295.

Dann, H. M., and J. K. Drackley. 2005. Carnitine palmityoltransferase I in liver of periparturient dairy cows: Effects of prepartum intake, postpartum induction of ketosis, and periparturient disorders. J. Dairy Sci. 88:3851-3859.

Dann, H. M., N. B. Litherland, J. P. Underwood, M. Bionaz, A. D'Angelo, J. W. McFadden, and J. K. Drackley. 2006. Diets during far-off and close-up dry periods affect periparturient metabolism and lactation in multiparous cows. J. Dairy Sci. 89:3563-3577.

Dann, H. M., D. E. Morin, G. A. Bollero, M. R. Murphy, and J. K. Drackley. 2005. Prepartum intake, postpartum induction of ketosis, and periparturient disorders affect the metabolic status of dairy cows. J. Dairy Sci. 88:3249-3264.

Delavaud, C., F. Bocquier, Y. Chilliard, D. H. Keisler, A. Gertler, and G. Kann. 2000. Plasma leptin determination in ruminants: Effect of nutritional status and body fatness on plasma leptin concentration assessed by a specific RIA in sheep. J. Endocrinol. 165:519-526.

Desvergne, B., L. Michalik, and W. Wahli. 2006. Transcriptional regulation of metabolism. Physiol. Rev. 86:465-514.

Douglas, G. N., T. R. Overton, H. G. Bateman II, H. M. Dann, and J. K. Drackley. 2006. Prepartal plane of nutrition, regardless of dietary energy source, affects periparturient metabolism and dry matter intake in Holstein cows. J. Dairy Sci. 89:2141-2157.

Douglas, G. N., T. R. Overton, H. G. Bateman II, and J. K. Drackley. 2004. Peripartal metabolism and production of Holstein cows fed diets supplemented with fat during the dry period. J. Dairy Sci. $87: 4210-4220$.

Doumas, B. T., W. A. Watson, and H. G. Biggs. 1971. Albumin standards and the measurement of serum albumin with bromcresol green. Clin. Chim. Acta 31:87-96.

Drackley, J. K., and H. M. Dann. 2008. A scientific approach to feeding dry cows. Chapter 3 in Recent Advances in Animal Nutrition-2007. P. C. Garnsworthy and J. Wiseman, ed. Nottingham University Press, Nottingham, UK

Drackley, J. K., H. M. Dann, G. N. Douglas, N. A. J. Guretzky, N. B. Litherland, J. P. Underwood, and J. J. Loor. 2005. Physiological and pathological adaptations in dairy cows that may increase suseptibility to periparturient diseases and disorders. Ital. J. Anim. Sci. 4:323-344.

Ehrhardt, R. A., R. M. Slepetis, J. Siegal-Willott, M. E. Van Amburgh, A. W. Bell, and Y. R. Boisclair. 2000. Development of a specific radioimmunoassay to measure physiological changes of circulating leptin in cattle and sheep. J. Endocrinol. 166:519-528.

Fletcher, M. J. 1968. A colormetric method for estimating serum triglycerides. Clin. Chim. Acta 22:393-397. 
Foster, L. B., and R. T. Dunn. 1973. Stable reagents for determination of serum triglycerides by a colorimetric Hantzsch condensation method. Clin. Chem. 19:338-340.

Friggens, N. C., J. B. Andersen, T. Larsen, O. Aaes, and R. J. Dewhurst. 2004. Priming the dairy cow for lactation: A review of dry cow feeding strategies. Anim. Res. 53:453-473.

Gaal, T., I. M. Reid, R. A. Collins, C. J. Roberts, and B. V. Pike. 1983 Comparison of biochemical and histological methods of estimating fat content of liver of dairy cows. Res. Vet. Sci. 34:245-248.

Greenfield, R. B., M. J. Cecava, and S. S. Donkin. 2000. Changes in mRNA expression for gluconeogenic enzymes in liver of dairy cattle during the transition to lactation. J. Dairy Sci. 83:1228-1236.

Grum, D. E., J. K. Drackley, R. S. Younker, D. W. LaCount, and J. J. Veenhuizen. 1996. Nutrition during the dry period and hepatic lipid metabolism of periparturient dairy cows. J. Dairy Sci. 79:1850-1864

Grummer, R. R., D. G. Mashek, and A. Hayirli. 2004. Dry matter intake and energy balance in the transition period. Vet. Clin. North Am. Food Anim. Pract. 20:447-470.

Guo, J., R. R. Peters, and R. A. Kohn. 2007. Effect of a transition diet on production performance and metabolism in periparturient dairy cows. J. Dairy Sci. 90:5247-5258.

Hara, A., and N. S. Radin. 1978. Lipid extraction of tissue with a lowtoxicity solvent. Ann. Biochem. 90:420-426.

Herdt, T. H. 2000. Ruminant adaptation to negative energy balance. Vet. Clin. North Am. Food Anim. Pract. 16:215-230.

Holtenius, K., S. Agenas, C. Delavaud, and Y. Chilliard. 2003. Effects of feeding intensity during the dry period. 2. Metabolic and hormonal responses. J. Dairy Sci. 86:883-891.

Holtenius, P. 1993. Hormonal regulation related to the development of fatty liver and ketosis. Acta Vet. Scand. Suppl. 89:55-60.

Hughes, J. P. 1962. A simplified instrument for obtaining liver biopsies in cattle. Am. J. Vet. Res. 23:1111-1113.

Ingvartsen, K. L., and Y. R. Boisclair. 2001. Leptin and the regulation of food intake, energy homeostasis and immunity with special focus on periparturient ruminants. Domest. Anim. Endocrinol. $21: 215-250$.

Janovick, N. A. 2008. Prepartum energy intake and its relationship to periparturient inflammation and metabolic dysfunction. PhD Diss. University of Illinois, Urbana.

Janovick, N. A., and J. K. Drackley. 2010. Prepartum dietary management of energy intake affects postpartum intake and lactation performance by primiparous and multiparous Holstein cows. J. Dairy Sci. 93:3086-3102.

Jin, H.-B., Z.-Y. Gu, C.-H. Yu, and Y.-M. Li. 2005. Association of nonalcoholic fatty liver disease with type 2 diabetes: Clinical features and independent risk factors in diabetic fatty liver patients. Hepatobiliary Pancreat Dis. Int. 4:389-392.

Jitrapakdee, S., and J. C. Wallace. 1999. Structure, function and regulation of pyruvate carboxylase. Biochem. J. 340:1-16.

Johnson, M. M., and J. P. Peters. 1993. Technical note: An improved method to quantify nonesterified fatty acids in bovine plasma. J. Anim. Sci. 71:753-756.

Koerner, A., J. Kratzsch, and W. Kiess. 2005. Adipocytokines: Leptin-The classical, resistin-The controversial, adiponectin-The promising, and more to come. Best Pract. Res. Clin. Endocrinol. Metab. 19:525-546.

Littell, R. C., P. R. Henry, and C. B. Ammerman. 1998. Statistical analysis of repeated measures data using SAS procedures. J. Anim. Sci. 76:1216-1231.

Lo, S., J. C. Russell, and A. W. Taylor. 1970. Determination of glycogen in small tissue samples. J. Appl. Physiol. 28:234-236.

Loor, J. J., H. M. Dann, R. E. Everts, R. Oliveira, C. A. Green, N. A. J. Guretzky, S. L. Rodriguez-Zas, H. A. Lewin, and J. K. Drackley. 2005. Temporal gene expression profiling of liver from periparturient dairy cows reveals complex adaptive mechanisms in hepatic function. Physiol. Genomics 23:217-226.

Mashek, D. G., and D. K. Beede. 2001. Peripartum responses of dairy cows fed energy-dense diets for 3 or 6 weeks prepartum. J. Dairy Sci. $84: 115-125$.
Mashek, D. G., K. L. Ingvartsen, J. B. Andersen, M. Vestergaard, and T. Larsen. 2001. Effects of a four-day hyperinsulinemic-euglycemic clamp in early and mid-lactation dairy cows on plasma concentrations of metabolites, hormones, and binding proteins. Domest. Anim. Endocrinol. 21:169-185.

McGarry, J. D. 2002. Dysregulation of fatty acid metabolism in the etiology of type 2 diabetes. Diabetes 51:7-18.

Minor, D. J., S. L. Trower, B. D. Strang, R. D. Shaver, and R. R. Grummer. 1998. Effects of nonfiber carbohydrate and niacin on periparturient metabolic status and lactation of dairy cows. J. Dairy Sci. 81:189-200.

Murondoti, A., R. Jorritsma, A. C. Beynen, T. Wensing, and M. J. H. Geelen. 2004. Unrestricted feed intake during the dry period impairs the postpartum oxidation and synthesis of fatty acids in the liver of dairy cows. J. Dairy Sci. 87:672-679.

National Research Council. 2001. Nutrient Requirements for Dairy Cattle. 7th rev. ed. ed. National Academy Press, Washington, $\mathrm{DC}$

Oba, M., and M. S. Allen. 2003a. Dose-response effects of intrauminal infusion of propionate on feeding behavior of lactating cows in early or midlactation. J. Dairy Sci. 86:2922-2931.

Oba, M., and M. S. Allen. 2003b. Extent of hypophagia caused by propionate infusion is related to plasma glucose concentration in lactating dairy cows. J. Nutr. 133:1105-1112.

Oikawa, S., and G. R. Oetzel. 2006. Decreased insulin response in dairy cows following a four-day fast to induce hepatic lipidosis. J. Dairy Sci. 89:2999-3005.

Peterson, J. I., and D. S. Young. 1968. Evaluation of the hexokinase/ glucose-6-phosphate dehydrogenase method of determination of glucose in urine. Anal. Biochem. 23:301-316.

Rabelo, E., R. L. Rezende, S. J. Bertics, and R. R. Grummer. 2003 Effects of transition diets varying in dietary energy density on lactation performance and ruminal parameters of dairy cows. J. Dairy Sci. 86:916-925.

Rabelo, E., R. L. Rezende, S. J. Bertics, and R. R. Grummer. 2005. Effects of pre- and postfresh transition diets varying in dietary energy density on metabolic status of periparturient dairy cows. J. Dairy Sci. 88:4375-4383.

Reynolds, C. K., P. C. Aikman, B. Lupoli, D. J. Humphries, and D. E. Beever. 2003. Splanchnic metabolism of dairy cows during the transition from late gestation through early lactation. J. Dairy Sci. $86: 1201-1217$

Roche, J. R. 2007. Milk production responses to pre- and postcalving dry matter intake in grazing dairy cows. Livest. Sci. 110:12-24.

Roche, J. R., E. S. Kolver, and J. K. Kay. 2005. Influence of precalving feed allowance on periparturient metabolic and hormonal responses and milk production in grazing dairy cows. J. Dairy Sci. 88:677-689.

Rukkwamsuk, T., T. Wensing, and M. J. H. Geelen. 1998. Effect of overfeeding during the dry period on regulation of adipose tissue metabolism in dairy cows during the periparturient period. J. Dairy Sci. 81:2904-2911.

Rukkwamsuk, T., T. Wensing, and M. J. H. Geelen. 1999. Effect of overfeeding during the dry period on the rate of esterification in adipose tissue of dairy cows during the periparturient period. J. Dairy Sci. 82:1164-1169.

Studer, V. A., R. R. Grummer, S. J. Bertics, and C. K. Reynolds. 1993. Effect of prepartum propylene glycol administration on periparturient fatty liver in dairy cows. J. Dairy Sci. 76:2931-2939.

VandeHaar, M. J., G. Yousif, B. K. Sharma, T. H. Herdt, R. S. Emery, M. S. Allen, and J. S. Liesman. 1999. Effect of energy and protein density of prepartum diets on fat and protein metabolism of dairy cattle in the periparturient period. J. Dairy Sci. 82:1282-1295.

Velez, J. C., and S. S. Donkin. 2005. Feed restriction induces pyruvate carboxylase but not phosphoenolpyruvate carboxykinase in dairy cows. J. Dairy Sci. 88:2938-2948.

Williamson, D. H., and J. Mellanby. 1974. D-(-)-3-hydroxybutyrate. Pages 1836-1840 in Methods of Enzymatic Analysis. Vol. 4. H. U. Bergmeyer, ed. Academic Press, London, UK. 